\title{
The Palm Landscapes of the Italian Riviera
}

\author{
Pietro Piana, Charles Watkins and Ross Balzaretti \\ University of Nottingham
}

\begin{abstract}
Palm trees are today a characteristic feature of tropical tourist landscapes around the world from Caribbean to the Maldives. They are also a distinctive element of Mediterranean landscapes. On the Italian Riviera they are frequently found in the grounds of villas and hotels, at railway stations and in public squares. This paper examines the changing landscapes of the palm trees of the Italian Riviera over the last 300 years. Palms, particularly Phoenix dactylifera, were an important element of the local economy cultivated especially for palm fronds to be sold for religious festivals. The widespread presence of palm trees gave stretches of the Ligurian coast an almost tropical character, especially around Bordighera and San Remo. These coastal towns became major health resorts in the late nineteenth century and international tourists and residents celebrated this exotic landscape. The palms became important subjects for amateur and professional artists and photographers and they proliferated in gardens, as street trees and in horticultural collections. They became signature trees for these wealthy therapeutic landscapes but rapid building development and the decline of the palm trade means that only fragments of the old palm plantations remain today and these are in need of careful conservation.
\end{abstract}

Keywords: Palm trees, Liguria, landscape, British travellers, Topographical Art

\section{Introduction}

Trees and vegetation have always had a major role in the characterization and visual perception of the landscape. Their distribution, density, shape and size reveals much about cultural and physical associations between people and the landscape (Watkins 2014). As well as for their aesthetic value, ancient woodlands are examined in historical ecology and landscape history studies (Rackham 1980, 2000; Dallas, Barnes and Williamson, 2015; Williamson, Barnes and Pillatt 2017). Recent research considers the relation between trees and art (Watkins 2018) and the representation of trees in topographical art for landscape research (McLoughlin 1999 Gaynor and McLean 2008). Less attention has been paid to the contribution of individual tree species in the making of particular landscapes. Research on the historical ecology and landscape history of the Italian mountains, particularly the Ligurian Apennines and the alpine region, has focussed on the chestnut tree (Castanea sativa; Cevasco, Moreno, Balzaretti and Watkins, 2015) and Turkey oak (Quercus cerris, Cevasco 2013). In coastal contexts, pines represent a typical landscape element and an important source of food and wood. A large number of topographical views and maps documents their current and past presence in Riviera landscapes (Piana et al. 2016; Moreno et al. 1993). 
Biogeographers and ecologists have studied palms for their interest as tropical relics on the Northern Mediterranean coast (C. Pintaud et al.2013; Giovino et al. 2014) In Liguria Orsino and Olivari (1987) focussed on the presence of autochthonous specimens of Chamaerops humilis at Portofino, which represents the northernmost station of this species in Europe. Scholars who focussed on the history of palm trees in the Ligurian Riviera have looked particularly at their economic and symbolic importance (Carassale et al. 2013). Littardi (2015) explores the symbolic significance of palms in the economy and the landscape of the Western Riviera between the thirteenth and the twentieth century.

Liguria (NW Italy) is characterised by contrasting coastal and mountainous landscapes within a very limited territory. The Western Riviera near the French border around Sanremo, Bordighera and Ventimiglia (Figure 1), which constitutes the focus of this work, has since the early nineteenth century been visited and described by a large number of visitors (Figure 1). By the end of the century the number of foreign residents, British in particular, was so high, that these towns were considered like 'British colonies in the Riviera' (Bartoli 2008; Zanini 2012). Their legacy survives in villas, churches, roads and libraries, but also in topographical views (prints, drawings, watercolours, oil paintings), historical photographs and written accounts (letters, travel books). In this paper we investigate the changing significance of palm trees in the landscape using these historical sources as well as field evidence.

\section{Cultivating palms in Liguria}

Two palm trees are native to Europe, Phoenix theophrasti, which has a very restricted population in Crete, and the more widespread Chamaerops humilis which is found in parts of Spain, France, Italy and north Africa. The range of the latter was restricted in the nineteenth century when it became a target for plant collectors and amateur botanists (García-Castaño, Terrab and Ortiz 2014; Hamilton 1883). The date palm Phoenix dactylifera has been cultivated in Asia and Africa for several thousand years and transported around the Mediterranean by the Greeks and Romans (Chao and Krueger 2007).

There are several legends about the introduction of date palms (Phoenix dactylifera) in Liguria. The most popular in the nineteenth century was that palms were introduced by returning sailors who had ferried Crusaders in the twelfth and thirteenth centuries (Hamilton 1883) or that they were introduced to Bordighera by Saint Ampelio from Egypt (Rossi 1892). A specific origin myth for the cultivation of palms at Bordighera was promoted by Giovanni Ruffini (1855 pp. 242-5) in his immensely popular novel written in English Doctor Antonio; A Tale of Italy. He recounts that Pope Sixtus V watched as the Egyptian obelisk was erected by the architect Domenico Fontana in St Peter's Square, Rome in October 1586 (described by Fontana 1590). At a crucial moment the ropes sagged, but the captain of a merchant vessel from Sanremo called out that they should be wetted, and the obelisk was successfully raised. The Pope in thanks gave the captain's family the monopoly of supplying palms to the Vatican for Palm Sunday and the Holy Week Services.

There is documentary evidence of the growing of palms in Liguria in the fifteenth century. This refers to the commercial production of palm branches for the church and 
notes that the fruit do not reach maturity. Giacomo Bracelli (1448) specified that they were found ten miles east of the River Roja at Sanremo and Flavio Biondo (1453) describes the lands of Sanremo 'rich in lemon trees and palms, the rarest trees in Italy (palmaeque, arborum in Italia rarissimarum)' (Biondo 2005). Fifteenth-century land registers have local names for 'palm' (e.g. Parma) in both coastal and inland areas of Sanremo, where palm trees were cultivated in mixed fields with lemons and oranges (Cassioli 2015, 88-89). In the eighteenth century one area with dense groves of palms was the Val di Sasso just to the east of Bordighera near the sea in the localities called Arzilla and Lonassa (Carassale 2015, 101). A map by the Genoese cartographer Matteo Vinzoni provides evidence of the importance of palm trees in the landscape of Bordighera (Figure 2). In the Val di Sasso, just inland from the Spiaggia d'Arzilla, he shows terraces with palms indicated by a specific palm tree symbol, which is not found on any other of his Riviera maps.

In the nineteenth century, the Val di Sasso became specialised for the production of palms, which were mixed with olive and lemon trees, vineyards and occasionally chestnuts (Carassale 2015). The cultivation of palms was a significant source of income for the people of Bordighera. Palms were exported to Genova, Sanremo, Marseille, Nice and other towns on the Riviera. In 1819 the inhabitants of Bordighera were described as 'fishermen, sailors and traders of olive oil, lemon trees and palms (which are cultivated locally) and of wine, wheat and other products (which are imported from the sea).' The production amounted to 800 barrels of olive oil, 400,000 lemons, 400,000 oranges, 300 palm bundles 'Jewish style' (12 lire each), 140 palm bundles (60 leaves each) 'roman style' (40 lire each) (Carassale 2015, 128). A drawing by an anonymous British amateur artist dating from c. 1830 is amongst the first known drawings of palms on the coast next to St Ampelio's church at Bordighera. The plantation with its carefully spaced trees contrasts with the wooded hills (Figure 3).

The topographer Davide Bertolotti (1834) provides a full description of the cultivation of palms in western Liguria in the early nineteenth century. At Sanremo he describes the seven hills surrounding the town 'covered in olives, cedars, lemons, oranges, palms, almonds, figs and pomegranates' (1834, vol. 1, 261), while at Bordighera the combination of olives and palms meant that 'The traveller thinks himself transported to Africa because of the very verdant and pyramidal aspect of this plant which is rare in Europe' (1834, vol. 1, 256). He attributes the cultivation of palms in Liguria to the Benedictine monks of the Abbey of San Fruttuoso on the Portofino peninsula where they 'transformed this rocky desert into a lovely garden.' (1834, vol. 3, 53).

Bertolotti $(1834$, vol. 3, 277) correctly identifies the two types of palms at Bordighera and Sanremo: the tall African Palm (Phoenix dactylifera) and the short European Palm (Chamaerops humilis). He notes that the former was grown for its palmizi. 'Palmizio' means the braided palm branches which were blessed on Palm Sunday and is given to the people as a sign of devotion. The production of palmizi was labour intensive. Bertolotti states that the farmer had 'to take extra care in tying the branches from the top in order to preserve the central shoot from the rays of the sun, removing the green colour and giving them that whiteness which is considered highly valuable.' The branches were tied up in June and July and untied in December when the bundle of palm fronds at the top of the tree was cut off and placed in a dark room. They were 'sent to Rome by the end of Carnival'. The English resident Frederick Hamilton 
$(1883,331)$ noted that 'turning the Palm leaves into a yellowish white colour, is produced by a process exactly similar to that employed by the market gardeners in obtaining the white centres of the lettuces.' The method was recently described in an interview by one of the last 'parmura' of Bordighera, Franco Palmero, in 2015. The 'parmura' climbed the palms with a rope made of hemp and cut the fronds growing outwards so he could reach the centre of the tree where he could stand. The fronds were tied using a rope made of Clematis vitalba which was collected from the woods and softened by soaking in water (Semeria 1871; Bernardini and Bessone 1971; Littardi, 2015, 71). A painting of 1883 by the German painter Ascan Lutteroth (1842 - 1923) shows a group of palms, two of which have their fronds tied up (Figure 4). A print published in 1873 is a rare depiction of the harvesting of palm fronds and the loading of cut fronds onto an oxcart (Figure 5).

The palm fronds were used in the churches of Rome and therefore called Roman style. The sales were organised by the same merchants who dealt with lemons. The palms were 'sorted in bundles of 60 shoots each, big and small' and the price of each bundle was between 20 and 30 lire. After the palm had been cropped the branches were 'left in their natural state for a year so that the tree increases in strength and regenerates new shoots.' Bertolotti also noted that there was distinct market for Jewish ceremonies. They required green palm fronds, and so the leaves were not tied up and blanched. Travellers and tourists noticed the specialised use of palms at church services. Anton Chekov writing to his family in 1891 was critical of the Riviera's luxurious lifestyle 'with its artichokes, its palm trees, and its scent of wild oranges!' but was fascinated that on Palm Sunday 'they have palm trees here instead of pussy willows' (Bartlett, 2004 p. 277). On Palm Sunday 1953 James Lees-Milne (1994, p.16) noted that his maid had bought two 'beautifully plaited' palms from the village shop 'mine in the shape of a Maltese cross, A.'s of a star, and both with tails.' At the church the children carried 'the most elaborate plaited palm branches hung with sweets in coloured papers and small witch-balls. The Curé carried a thin, long palm branch like a pheasant's tail, waving.'

A general threat to palm cultivation was the insect (Calandra scaba). Molinari (1869) states that there were 12,000 palms in Bordighera in 1869 compared to around 50,000 olive trees and 36,000 citruses. Carassale $(2015,138)$ quotes Mario Calvino who stated in 1900 that the production of palmieri in San Remo had declined considerably in recent years because 'as the city grew, as the gardens and villas spread, all the places where the palm trees were cultivated became ornamental and the plants were no longer subjected to binding'. In Bordighera on the other hand the culture of palms remained extensive and profitable into the twentieth century. But the market for palm fronds declined in the 1960s and tourism and other sources of income became dominant. Many terraces were abandoned and palm trees remained uncut or were replaced with other crops such as asparagus, mimosa and eucalyptus for decorative foliage. Moreover, large old trees themselves became a valuable commodity and were dug up and sold for ornamental use (Littardi 2015, n. 126).

\section{'Lands of palm' and British travellers}

One of the first mentions of palms on the Riviera by British travellers is by John Ruskin writing from Oneglia [24 April] 1845 who notes that he has 'been working up 
a hurried sketch taken at St Remo, of a beautiful bit of palace \& two splendid palm trees growing in the street, almost unique.' A few years later Alfred Tennyson in his poem The Daisy (1853) written after travelling with his wife along the coast celebrated the palms they had experienced:

' $O$ love what hours were thine and mine

In lands of palm and southern pine

In lands of palm, of orange blossom,

Of olive, aloe, and maize and vine'

But he did not find the cultivated palms 'the clipp'd palm of which they boast' pleasing. In the same year the popularity of the Riviera for British tourists was enhanced by the runaway success of Giovanni Ruffini's novel Doctor Antonio first published in English in 1855 and in Italian translation in 1856. Giovanni Ruffini (1807-1881), was born in Genoa and, a keen supporter of Mazzini, lived in exile in London and Paris for much of his life. He worked with Donizetti on the libretto for Don Pasquale in 1843 and wrote several novels. Doctor Antonio is set in 1840 and recounts a platonic love story between a revolutionary doctor and the wealthy daughter of an English baronet set in a carefully cultivated, bucolic landscape (Christensen 1984; Pagano 2015). When Lucy first sees the palms she is mystified 'did I imagine or really see big palm-trees on the hill of Bordighera?' she asks Antonio who tells her that 'Bordighera is famous for its palm-trees' (104). Later she exclaims 'What an Eastern look those waving palms give the hill of Bordighera! One might believe one's self in Asia Minor.' (162) She goes on to say 'I cannot take my eyes from those palm-trees, they make me think of crusades and knights all mixed up with Scripture stories'. Later she tries to draw some palms but thinks her sketch 'is all in a mess'; Antonio's advice is that she has been 'too greedy.... You see that halfruined tower shaded by palm trees, on the Cape of Bordighera? - try that first...' While on a visit to nearby San Remo Lucy asked 'pointing to the plantations that covered the shore' whether 'palm-trees grow naturally in this part of the country?... or are they cultivated for beauty's sake?'. Antonio answered that 'Their beauty, I believe, is their least merit in the eyes of their proprietors' and pointed out that 'Palms, you do not perhaps know, are a very profitable kind of property, and that is why they are cultivated.' (241)

Even Lucy's father, Sir John Davenne eventually becomes infatuated with the palms. Initially he is horrified by their association with 'idolatrous' Roman Catholic crucifixes and plaster casts of the holy Virgin found in 'the bedrooms of the poorer houses' (45). But he decides he is going 'to make a collection of the finest orange and palm plants to be found in the neighbourhood, and transplant them to the seigneurial seat of all the Davennes' in Kent. He contacts 'all the owners of palm trees in Bordighera - Bordighera which stands unrivalled for palm-trees' and intends to 'build a palmary; Lucy, a palmary!'.... 'You see, my dear, I shall not only create the thing, but the very name of it'. (181)

The palms attracted artists; one of the earliest was the British artist William Wyld (1806-1889) who painted the plain of Bordighera entirely wooded with orange, olive and palm trees (Figure 7). Wyld lived for much of his life in Paris and became well known for orientalist paintings, and this painting of the palms of Bordighera slips easily into this genre. The orientalist associations of the palms were picked up by 
early tourist writers such as Francesco Bonalumi $(1873,55)$ in his Fotografie poetiche della Riviera Occidentale da Porto Maurizio ed Oneglia which describes Bordighera as 'the Jericho of Liguria where 'the girls, new Rebekkas, go down to draw water from the wells encircled by palms.'

The publication of Henry Alford's influential guide to the Riviera in 1870 perhaps marks the point when the palms of Bordighera became themselves one of the reasons for visiting the Riviera. Alford, Dean of Canterbury, is probably best known today as author of the harvest hymn 'Come, ye thankful people, come'. He was a biblical scholar, poet, friend of Alfred Tennyson and regular contributor to literary magazines such as the Contemporary Review. In February 1869 he set off for 'six weeks alone with Nature' after a hard winter's labour in charge of 'the enthronement of our new Archbishop' and published his tour in 1870 as The Riviera: Pen and Pencil Sketches from Cannes to Genoa (Figure 7). Alford criticises those who claimed 'that they had seen from the high road all that was to be seen of the palms of Bordighera'. He emphasised that 'The palm-glory of Bordighera is not to be seen without going up into the town, and beyond the town' where the 'noble' palms 'almost gird it round on the western and northern sides, and grow in profusion - in coppices and woods - of all sizes, from gnarled giants of 1100 years' reputed age, to little suckers which may be pulled up by hand, and carried to England.' He stressed the aesthetic aspects of the trees and thought that 'there is no end to the picturesque groupings of these lovely trees, and their graceful effects in the sunlight.'

From an artists' perspective he felt that the palm was 'the best purveyor of flecked and dancing shade.' In the 'palm-thickets every darkest spot of shadow is a grand medley of exquisitely traced lines; and on the verge of the bare sunlight outside, leap and twinkle a thousand sharply marked parallel bars of graceful leafage.' He used the vocabulary of the palette to identify the special advantages of the palm: 'the yellow, and the pale green, and the rich burnt sienna of the various foliage; the rough deep markings of the rich brown stem; and now and then the burning chrome of the fruit stalks hanging in profuse clusters...'. The visual attractions were supplemented by the sounds of the leaves: 'the silvery whisper of reeded fronds which dwells everywhere about and under it.' Alford was also keen to emphasise the biblical connotations of the palms. 'I have been told that there are probably now more palms at Bordighera alone, than in the whole of the Holy Land' (Alford 1870, 72).

To assist the visitor to Bordighera who wished to sketch the palms he outlined a precise itinerary through the town to take in the best views of palms. View 1 could be seen from near the arch in the town wall over 'some old battlements' and allowed a comparison between tree forms: 'several graceful palms, and a cypress in marked contrast, with its solid vertical dark spire, to the feathery palm-fronds gleaming against the heavenly blue.' This viewpoint was selected because there was a view to the 'distant jagged outline of the Estrelles' and 'you will not again see the palms thus cutting the far off coast-line' (p.73). For the second view the artist had to walk through the arch and stand 'a little above a baker's shop' and 'in the middle of the paved gangway'. This view took in a 'mass of ancient palms' above which was 'a strip of bright sea' with 'creamy pink hills in the distance.' The early impact of tourism on some Bordighera residents is hinted at from his aside that the ancient palms he so admired were 'in the garden of a Signor $\mathrm{M}-$, known for his propensity to show out very summarily any intruders into his grounds, even if they have acted on 
former permissions to enter.' However, he did gain permission, and the third view is in the garden of old palms: 'Truly, there are palms and palms; and these are of the first order.' Alford alludes to the possibility that the palms used to belong to 'Capuchin monks' but is mainly dazzled by their sheer physicality. These 'giants' 'tower into the sky' and 'we vainly tried to embrace their ample stems'. Moreover these ancient garden palms, not cultivated for their palmizi, were 'loaded with their dazzling fruitage: we pick up and eat the soft sweet dates which strew the ground.' Alford relishes close encounters with the palms: 'a gigantic palm has fallen (or grown) prostrate on the wall' and 'arches over the way, so you are obliged to stoop to avoid its clubbed knots.'

Alford recommended that visitors then walked out of the medieval town to stand behind a pool where 'a bevy of washerwomen ply their trade' (74). Sketches of women washing clothes in pools or rivers was one of the most popular subjects for artists in the nineteenth century. But the view Alford was recommending was of 'Bordighera church amidst a thicket of palm, and the sea glittering with the glare of noon.' Once this had been sketched the visitor was free to wander 'between the town gardens and the olive yards' and 'Over you, and around you, and below you, palms, palms: many a group which might occupy a painter for a month.' Alford enthused that if the 'rambler descends into the bed of the torrent' there are 'promontories on either side, outlined by the feathery tops of a hundred palms' and looking up 'the gorge, the woods seem full of them.'

The final viewpoint was about two miles from the town where there was 'a group of palms down on the rocky shore, with a path leading among the trunks. Beneath them a low cliff drops to the tumbling swell.' (74-5) The picturesque possibilities of the site were enhanced for Alford by 'what might have been a tomb - an oblong stone-fenced enclosure.' He found it 'a dreary spot - such as a morbid man might choose to be buried in' and remembered it from his first visit to Bordighera in 1862 when he had seen it from his carriage and 'many times since has that vision of the solitary palmgrove, and the oblong enclosure, and the foamy sea beneath'. For Alford the palms strongly resonated with religious imagery and as he looked back on this 'idyll of palms' and 'cut the edges of his sketches' he dreamt of 'a certain procession... down the stony path from Olivet' and 'of a joyous multitude who strewed in the way these same graceful, softly-rusting fronds.' Here the voice of the Anglican biblical scholar comes to the fore.

\section{Palms as international landscape therapy}

In the second half of the century, and especially after the opening of the coastal railway in 1872, many British, French and German visitors became seasonal or permanent residents on the Riviera. The climate was recognised as ideal for northern Europeans in search of a winter health resort (an article in The Lancet in $1868 \mathrm{had}$ praised its therapeutic qualities) and the new kingdom of Italy was seen as relatively politically stable (Walker 1868; Bennet 1875; Thomson 2018). Those attracted include the French architect Charles Garnier who built his own large villa on the coast (1871-3) with a tower with views of the sea, the coast, the old town of Bordighera and extensive groves of palms. The German botanist Friedrich August Fluckiger noted in 1877 that 'well-informed persons estimate the palm trees in Bordighera at 10,000' (Fluckiger 1877, 31). A guide to Bordighera by Frederick Hamilton $(1883,332)$ noted 
that the 'Campanile' of M. Charles Garnier's pretty villa gives a lovely view of these oriental gardens, which are on every side of it.' Garnier helped to develop the town and built a very large villa for the French financier Raphael Bischoffsheim. Towards the end of Alphonse Daudet's 1877 novel Le Nabob a chapter is set in Bordighera where 'the scattered villas stood forth in dazzling whiteness' and a banker's villa was 'recognizable by the capricious richness of its architecture and the height of its palmtrees.' (Daudet 1877 [1898], Vol 2, 275) The settlers were attracted by the landscape and lush vegetation and amongst them were some keen botanists and horticulturalists who introduced new palm species.

Perhaps the most important of these gardeners were the Quakers Thomas Hanbury (1832-1907) and his brother Daniel (1825-1875). Thomas Hanbury was a very wealthy tea, silk and cotton merchant at Shanghai while his brother Daniel was a pharmacologist and botanist in London. 'It had been a dream of Thomas Hanbury from his early youth to make a garden in a southern climate, and share its pleasures and botanical interests with his favourite brother.' (Berger 1912 p. x). Thomas bought the Palazzo Orengo and its estate 'intending that he and Daniel, whose interest lay in medicinal plants, would create a botanical garden' in 1867 (McConnell 2009). Their first step was 'to increase the natural vegetation on the wild parts of the property, then almost denuded by the unchecked depredations of the neighbouring peasants, who had freely cut the trees and brushwood, and pastured their goats on the scanty herbage.' They sowed seeds of indigenous shrubs and trees such as Rhamnus alaternus and Quercus Ilex which were 'then scarce or non-existent' and these soon formed 'abundant evergreen undergrowth.' (Berger 1912). They then started to establish a subtropical botanical garden with many medicinal plants covering 18 hectares. They amassed and cultivated a huge collection of exotic plants. Gustave Cronemeyer, who was curator of the gardens between 1883 and 1892 (Mariotti 2017) listed 3,600 species in his catalogue of 1889 (Berger 1912; Cronemeyer 1889). There was a botanical museum and library and a 'herbarium of cultivated and indigenous plants' and plants were received from across the world including South Africa, India, California, Germany, Austro-Hungary, France, Italy and USA. Seeds were distributed to many botanical gardens and in 1908 13,085 packets were sent out (Berger 1912).

The gardeners included the German landscape architect and entrepreneur Ludwig Winter who helped to plan the layout and stock the gardens. The Hanburys found only one palm in the garden, and this soon blew down, but a sucker from it flourished. By 1912 there were 'several big old specimens, all planted by Sir Thomas Hanbury' (Berger 418). Berger (1912 380) notes that the dwarf palm Chamaerops humilis 'though once indigenous on the Riviera, has now disappeared as a wild plant, but is much grown in gardens'. It was introduced at La Mortola from Hyères in December 1867 and further introductions were made from the Jardin d'Essai, Hamma, Algeria in 1873.

Ludwig Winter settled in Bordighera in the 1870s and established nurseries at 'Giardino delle braie' and started planting palms in Val di Sasso in the 'giardino delle Lonasse' (Viacava 1996; Littardi 2015). Winter's gardens themselves became a tourist attraction and were advertised in the local international newspaper the Journal de Bordighera (Tuesday 8 December 1898) as 'Scheffel's Palms, near Madonna Della Ruota' a 'beautiful group of palms stands in a fine garden on the promontory below the Madonna della Ruota, on the Ospedaletti road. For cards of admission apply to 
Sig. L. Winter Bordighera.' He advertised his services for the 'Culture et Exportation de Palmiers et d'autres Plantes de Décoration' and the 'Création de jardins et de parcs'. Winter also made ornamental souvenirs for tourists such flower baskets and small work baskets from plaited palm-branches, utilizing the remains of the dried branches especially from Chamaerops humilis. There were many German visitors to Bordighera, and the Scheffel palms were named after the popular German poet Joseph Victor von Scheffel (1826-1886) who had been fascinated by the palms on a visit in 1853 and described them in his influential poem 'Near Death' in 1856. That this poem remained very popular can be seen in the autobiography of the German Nobel Prize winning chemist Wilhelm Ostwald (1853-1932) who following a nervous breakdown in 1895 needed a complete rest and "travelled to the Mediterranean to get as much sun as possible. I stayed in Bordighera just because of the "seven palms by the seashore" mentioned in J. V. Scheffel's expressive poem.' (Jack and Scholz, 2017, 260).

The increasing popularity of palms and the rise of tourism caused local authorities to consider planting street trees and avenues so that visitors received a suitable impression of wealth and healthy climate. The popularity of Nervi, near Genoa, as a health resort increased once the Genoa to La Spezia railway opened in 1874 (Piana, Watkins and Balzaretti, 2018). There was a need for a new road from the coastal railway station to the town centre. The first controversial plan included a $15 \mathrm{~m}$ wide road, with $4 \mathrm{~m}$ wide pavements, the canalization of a river 'for the benefits and health of the population' and the establishment of ornamental trees. This was opposed by farmers whose fields would have been expropriated, but the road was eventually built in 1877 , with the adjoining villas in 1881 . The town council appointed a commission of three experts to design the new plantings and 'stupendi palmizi' (beautiful palm trees) and orange trees were planted. Agostino Luigi Sacchi (1867-1940) painted an arresting image used in a tourist poster (c. 1905) of a couple riding up the palm avenue with the sea and coastline towards Portofino in the distance (Figure 8). The Avenue de Palmes, which remains today, provided an impressive entrance to the resort from the railway station (Gajone, 1955).

A few years later a similar avenue leading up from the railway station was established at Bordighera. The Journal de Bordighera of 3 November 1898 noted the very rapid growth of the town over the previous two decades and that "now that we have a public supply of water and the electric light we may fairly claim to rank as one of the foremost health resorts of the Riviera.' The newspaper was pleased that a new road had been built from the station to the Strada Romana, where many of the hotels and villas were found, and noted that 'We are glad to hear that there is some idea of planting it with palms on either side.' This would 'add materially to the picturesque effect of the road and would not fail to give visitors on their first arrival at the railway station, a favourable impression of the beauty of our town.' The editor thought that 'some of our residents would be willing to give from their own gardens, contributions of palms to attain this end' and help to ameliorate the landscape. By the end of the nineteenth century palms were commonly being planted as street trees, and valued for their contribution to the local tourist economy.

Palms were also increasingly valued as subjects for painters. Some health tourists, such as the chemist Wilhelm Ostwald attempted to use painting as therapy. He recounted that on his visit to Bordighera 'To fill the many empty hours that faced me I took my paint box and a large stock of paints as well as my photographic material.' (260) He kept to a strict routine 'of getting up early and going off on lonely walks with my paint box' (261) (Jack and Scholz 2017, 260-1). The Val di Sasso near 
Bordighera became an iconic landscape and many artists depicted the palm groves and Ludvig Winter's garden. A large oil painting of the Val di Sasso by the German artist Herman Nestel (1888) was widely disseminated through prints which helped to increase the popularity of the Val di Sasso in the late nineteenth century. Nestel also painted a fresco of the Val di Sasso for the luxurious Hotel Angst in Bordighera. These paintings and drawings depict a lush and verdant landscape with terraces and dry stone walls. As in other parts of Liguria, the terraces here were used for mixed cultivation within the same fields known as 'coltura promiscua'. In the Sasso Valley the palm trees were planted along the edge of the terraces providing shelter and shade for seasonal vegetables and legumes and fruit trees such as figs, oranges and pomegranates. The water of the Sasso stream was partly diverted by a channel (called Beodo in the local dialect) which runs along the hillside terraces supplying water to Bordighera and irrigating the terraces and is shown in an anonymous watercolour with tied palms (Figure 9).

The most famous of the artists who visited Bordighera in this period is Claude Monet (1840-1926) who stayed for three months in 1884. His friend Renoir had visited the town briefly on his way to Venice in 1881 , and in December 1883 they had travelled together by train along the coast to Genoa and back to Antibes (Thomson 2018, 220). Many of his Bordighera paintings include palms, including those depicting the Villa Bischoffsheim such as Villas at Bordighera 1884 (66). But he was particularly delighted to gain access to the private garden owned by Francesco Moreno (the same garden with a potentially 'difficult' owner that Alford mentions in 1870 and where Fluckinger observed 'seedlings spontaneously growing from fruits dropped from the palms', 1877, 32) which according to some guidebooks 'had more palms and other subtropical species' than any in Europe (Thomson 2018, 68). He was particularly enamoured of the 'lavish ochres of the palm fronds' shown in his painting of a cottage almost buried in palms in Small Country Farm at Bordighera. Un coin de ferme à Bordighera (Figure 10). He told friends in Paris that 'These palms are driving me crazy; the motifs are extremely difficult to seize, to put on canvas; it's so bushy everywhere, although delightful to the eye....' (Monet, Bordighera January 1884 in Day and Sturges 1987, 100)

More typical views of the palms were provided by photographers such as Geoffrey Ronald Ballance, whose Bordighera, c. 1920 shows the palms on the rocky cliffs at Bordighera (Figure 11). The amateur artist Max Nadenbousch's watercolour of the gardens of his father-in-law's famous Hotel Angst (c.1920) shows several palms, a fountain and distant views of the hills towards France (Figure 12). These representations demonstrate that by the early twentieth century memories of traditional palm plantations and cultivation for ecclesiastical use had largely disappeared. The palm was firmly established as a symbol of luxurious gardening and wealthy health tourism.

\section{Palm landscapes today}

What of the conservation of palms today? Superficially the future of palms on the Riviera seems assured. At Bordighera, palms are still frequently found as street trees and in parks. A census of the palms by the Bordighera City Council in 2003 showed that there were 20 palm species and a total of 1,458 trees of which $68 \%$ were Phoenix dactylifera and 16\% were Phoenix canariensis (Carassale 2013). There have been 
many new plantings along the coast associated with expanding marinas and redeveloped hotels. At Genoa 200 mature $15 \mathrm{~m}$ tall palms purchased from Egypt were planted in 2001 at the Porto Antico, following plans by Renzo Piano, as part of the landscaping of the city prior to the G8 summit. The planting costs were around $€ 6,200$ per tree but many have since succumbed to disease and there are no plans to replace those that die (La Repubblica 30 November 2001). Palms are also still planted at the entrances to towns, at Sestri Levante, for example, the road from the autostrada junction to the town is lined with 30 year old palms. But many of these palms are under threat from the red palm beetle known in Italian as Punteruolo rosso (Rhynchophorus ferrugineus) (DEFRA 2016). This highly invasive pest is native to southern Asia but spread rapidly in the 1980s and from 2000 onwards reached many parts of the Mediterranean. Infestation often causes the palm tree to die and many mature palms in danger of collapse have had to be felled and removed. Many of the palm trees that for many years were well established features of railway stations, as at Rapallo, have been felled.

More positively, some fragments of the old traditional palm plantations survive in places like the Val di Sasso, and as semi wild populations in the river valleys at Taggia and Nervi. Field visits to the Val di Sasso in 2017 and 2018 (Figure 13) showed that although traditional palm management had been abandoned there were many surviving palm trees along the valley. Many terraces are now abandoned and overgrown with pioneer vegetation such as broom (Genista spp.) and tree heather (Erica arborea). Semi-spontaneous plantations of the palm Chamaerops humilis, with scattered specimens of Phoenix canariensis, are found along the terraces (Figure 14). Palm trees are often surrounded by olive trees, isolated eucalyptuses and clumps of mimosa. The presence of water channels and the river creates a microclimate with hygrophilous species such as Adiantum capillus-veneris, Prunella vulgaris and Equisetum spp. The eucalyptus has been grown since the 1970s for the production of decorative foliage (Minuto 2001). Native broadleaved species such as the manna ash (Fraxinus ornus), downy oak (Quercus pubescens) and conifers like the Aleppo pine (Pinus halepensis) grow along the river. Higher up the valley palms grow amidst regenerating semi natural woodland of elm (Ulmus minor), hazel (Corylus avellana) and alder (Alnus glutinosa).

Various conservation schemes have been established to protect and publicise the history and conservation of palms. Progetto Phoenix is run by the Città di Bordighera to examine the history and conservation of historical palm cultivation in the area. The old water canal or Beodo which once supplied water for the town of Bordighera and for irrigation, has recently (2015) been restored with EU Regional Development funding. Its associated footpath, so celebrated by nineteenth century authors, starts from the Cittá Alta of Bordighera and runs along the western side of the valley between gardens, traditional cottages and water tanks for irrigation, eventually reaching the village of Sasso.

The historical fame of the Val di Sasso survives in the memory of the local inhabitants: in an interview, the novelist Italo Calvino's gardener Libereso Guglielmi recalled the palms of the Val di Sasso, like the landscape of an oasis in Africa, stressing the importance the water canal for the cultivation of the trees (Guglielmi 2013). A Facebook group for users of the path and local residents has been established and a more difficult path leading all the way to the village of Sasso has been reopened and guided walks are advertised. The restored paths provide a rare 
route for tourists to leave the beaches and visit and enjoy this once famous but now largely forgotten and gently decaying exotic landscape.

\section{Conclusions}

This paper has explored the complex cultural and historical geographies of palms on the Italian Riviera. The historical importance of palm cultivation for Christian and Jewish religious festivals from the Middle Ages to the early twentieth century has been revealed. Traditional palm cultivation informed and influenced early tourism in towns such as Bordighera and San Remo during the second half of the nineteenth century directly through their effects on visitors and residents, and indirectly through the depiction of palms in poems and novels. The role of amateur and professional artists was vital in inventing and reinforcing the cultural signature of palms associated with the Riviera. In the twentieth century the importance of palms for tourism and recreation soon replaced their original function. Moreover, botanical collections (such as La Mortola) and professional gardeners, such as Ludwig Winter, became very active in driving a fashion for planting palms in private villa and hotel gardens. Town authorities at places such as Nervi and Bordighera soon realised that palms were an important way to stimulate tourism and attract visitors and residents to the rapidly developing coastal heath resorts. Palm avenues and public parks were used to advertise the exotic nature of the resorts for passengers arriving at the new railway stations. Only a few fragments of the old plantations which adorned the landscape of the Riviera and attracted tourists survive. Several conservation schemes are currently taking place in the Val di Sasso place to help conserve this unique landscape. The wide range of iconographical sources and historical documents, combined with field data, provide insights and perspectives for these management policies.

\section{Acknowledgments}

The authors would like to thank the staff of the Collezione Topografica, Comune di Genova and Eng. Giuseppe Bessone for giving permission to publish pictures from his collection.

\section{Disclosure Statement}

The authors declare that there is no conflict of interest regarding the publication of this article.

\section{Bibliography}

Alford, H. 1870. The Riviera: Pen and Pencil Sketches from Cannes to Genoa, Bell \& Daldy, London.

Andriani, G. 1924. 'Giacomo Braccelli nella storia della geografia', Atti della Società Ligure di Storia Patria, LII, 127-248.

Bartlett, R. 2004. Anton Chekhov. A life in letters, Penguin, London. 
Bartoli, A. 2008. The British colonies in the Italian Riviera in '800 and '900, Fondazione De Mari, Cassa di Risparmio di Savona, Savona.

Bennet, J. H. 1875. Winter and Spring on the Shores of the Mediterranean, fifth edition, J. \& A. Churchill, London.

Berger, A. 1912. Alphabetical Catalogue of Plants growing in the garden of the late Sir Thomas Hanbury at La Mortola, Ventimiglia, Italy, West, Newman \& co., London.

Bertolotti, D. 1834. Viaggio nella Liguria Marittima, 3 vols, Botta, Torino.

Bernardini, E. and Bessone, G. 1971. Bordighera ieri, Comitato Celebrazioni 500 anniversario fondazione Bordighera, Bordighera.

Biondi, Flavio (1453), 2005. Italy illuminated, vol. 1 (Books 1-IV), ed.and trans. by J. A. White, Harvard University Press, Cambridge, Mass.

Bonalumi, F. 1873. Fotografie poetiche della Riviera Occidentale da Porto Maurizio ed Oneglia, volume 1, 2nd edition, Ghilini, Oneglia.

Braccelli, G. 1448. Descriptio orae ligusticae. In G. Andriani, 'Giacomo Braccelli nella storia della geografia', 233-37.

Calvino, M. 1900. Brevi cenni sulla cultura delle palme nel territorio di Sanremo. L'Agricoltura Italiana 26, 162-5.

Carassale, A., Castellana, R., Dore, M., and Veziano, P. 2013. The historic phoeniciculture in Italy: Description of the medieval palm grove of Bordighera (Sanremo-Liguria) and of the Italian palms craft. Acta Horticulturae, 994, 39-52.

Carassale, A. 2015. Le palme di Sanremo e Bordighera: normative di raccolta e circuiti commerciali (secc. XV-XX). In Palme di Liguria, ed. C. Littardi, Carocci, Roma, 93-150.

Cassioli, M. 2015. La palma nel paesaggio agrario dell'estremo Ponente Ligure: il territorio di Sanremo alla fine del Medioevo. In Palme di Liguria, ed. C. Littardi, Carocci, Roma, 82-89.

Cevasco, R., Moreno, D., Balzaretti, R and Watkins, C. 2015. Historical chestnut cultures, climate and rural landscapes in the Apennines. In The Future of Heritage as Climate Changes, eds D. Harvey and J. Perry, Routledge, London, 131-147.

Cevasco, R. 2013. Dai cerri da foglia alle lupinelle: tracce dalle sequenze medievali e post-medievali del Lago di Rezzo (Val d'Aveto, Rezzoaglio - GE). In La Natura della Montagna. Scritti in ricordo di Giuseppina Poggi, ed R. Cevasco, Oltre edizioni, Sestri Levante, 105-120.

Chao, C. and Krueger, R. 2007. The Date Palm (Phoenix dactylifera L.): Overview of Biology, Uses, and Cultivation. HortScience 42, 1077-1082. 
Christensen, A. 1984. Giovanni Ruffini and Doctor Antonio: Italian and English contributions to the myth of exile. Browning Institute Studies 12, 133-154.

Cronemeyer, G. 1889. Systematic catalogue of plants growing in the open air in the garden of Thomas Hanbury, Palazzo Orengo, La Mortola, G.A. Koening, Erfurt.

Dallas, P., Barnes, G. and Williamson, T. 2015. Orchards in the Landscape: a Norfolk Case Study. Landscapes 16, 26-43

Daudet, A. 1877. The Nabob. English translation by Burnham, G. I. 1902. Boston, Vol 2, 275 http://www.gutenberg.org/files/21329/21329-h/21329-h.htm

Day, H. T. and Sturges, H. 1987. Hollister, Joslyn Art Museum: Paintings and Sculpture from the European and American Collections,

DEFRA (2016) Red Palm Beetle

https://planthealthportal.defra.gov.uk/assets/factsheets/Rhynchophorus-ferrugineusDefra-PP-Factsheet-Oct-2016-FINAL3.pdf

Fluckiger, F. A. 1877. An Easter Holiday in Liguria, London.

Fontana, D. 1590. Della trasportatione dell'obelisco vaticano et delle fabriche di nostro signore papa Sisto V, fatte dal cavallier Domenico Fontana, architetto di Sva Santita, Rome.

Gaynor, A. and McLean, I. 2008. Landscape Histories: Mapping environmental and ecological change through the landscape art of the Swan River Region of Western Australia. Environment and History 14, 197-204.

Gajone, A..1955. Nervi, Sant'Ilario e Quinto al Mare, Storia e Turismo, Bertello Borgo S. Dalmazzo.

García-Castaño, J. L., Terrab, A., and Ortiz, M. A. 2014. Patterns of phylogeography and vicariance of Chamaerops humilis L. (Palmae). Turkish Journal of Botany 38, 1132-1146.

Giovino, A., Scibetta, S., Saia, S. and Guarino, C. 2014. Genetic and morphologic diversity of European fan palm (Chamaerops humilis L.) population from different environments from Sicily. Botanical Journal of the Linnean Society, 176, 66-81.

Guglielmi, L. 2013. Libereso il giardiniere di Calvino, Orme editori, Mulazzo (MS).

Hamilton, F. F. 1883, Bordighera and the western Riviera, Stanford, London.

Jack, R. S. and Scholz, F. (eds). 2017. Wilhelm Ostwald: The Autobiography, Springer.

Lees-Milne, James. 1994. A mingled measure (diaries 1953-1972), John Murray, London. 
Littardi, C. 2015. Il palmeto storico dell'estremo Ponente Ligure; evoluzione, forma e utilizzo. In Palme di Liguria, ed. C. Littardi, Carocci, Roma, 20-81.

Mariotti, M. 2017. The contribution of some German personalities to botanical culture in Liguria (NW Italy) between 19th and 20th centuries. Boll. Mus. Ist Biol. Univ. Genova 79, 136-165.

McConnell, A. 2009. Hanbury, Sir Thomas (1832-1907), merchant and gardener. Oxford Dictionary of National Biography. Retrieved 19 Sep. 2018, from http://www.oxforddnb.com/view/10.1093/ref:odnb/9780198614128.001.0001/odnb9780198614128-e-54055.

McLoughlin, L. 1999. Vegetation in the early landscape art of the Sidney region, Australia: accurate record or artistic licence? Landscape Research 24, 25-47.

Minuto, L. 2001. La copertura vegetale, naturale e antropica del Vallone del Sasso. In La tutela del patrimonio ambientale e del palmeto di Bordighera, ed. Istituto Internazionale di Studi Liguri, 17-34,

Molinari, G. 1869. Cenni storici sulla Bordighera, suo territorio e clima, Carlo Puppo, Sanremo.

Moreno, D., Croce, G. F., Guido, M. A. and Montanari, C. 1993. Pine plantations on ancient grassland: Ecological changes in the Mediterranean mountains of Liguria, Italy, during the $19^{\text {th }}$ and $20^{\text {th }}$ centuries. In Ecological Effects of Afforestation. Studies in the history and ecology of afforestation in Western Europe, ed. C. Watkins, CAB, 93-110.

Orsino, F. and Olivari, S. 1987. The presence of Chamaerops humilis L. on Portofino promontory (East Liguria). Journal of Plant Taxonomy and Geography 41, 261-272.

Pagano, T. 2013. Giovanni Ruffini's Doctor Antonio and the healing power of the Italian landscape. Forum Italicum 47 (2) 287-298.

Pagano, Tullio. 2015. The Making and Unmaking of Mediterranean Landscape in Italian Literature: The Case of Liguria, Fairleigh Dickinson University Press, Madison.

Pintaud, J. C., Ludeňa, B., Aberlenc-Bertossi, F, et al. 2013. Biogeography of the Date Palm (Phoenix Dactylifera L., Arecaceae): insights on the origin and on the structure of modern diversity. Acta Horticulturae 994, 19-38.

Piana, P., Watkins, C. and Balzaretti, R. 2016. 'Saved from the sordid axe': representation and understanding of pine trees by English visitors to Italy in the eighteenth and nineteenth century. Landscape History 37, 35 - 56.

Piana, P., Watkins, C. and Balzaretti, R. 2018. Travel, modernity and rural landscapes in Nineteenth-Century Liguria. Rural History 29, 167-193. 
Quaini, M. 1983. Pianta delle due riviere della Serenissima Repubblica di Genova divise ne’ commissariati di Sanità, Sagep, Genova.

Rackham, O. 1980. Ancient Woodland, its History, Vegetation and Uses in England, Edward Arnold, London.

Rackham, O. 2000. Prospects for Landscape History and Historical Ecology. Landscapes 1, 3-17.

Rossi, F. 1892. Santo Ampelio, I suoi tempi e la palma colla loro coltivazione in Bordighera, Gibelli, Bordighera.

Ruffini, G. 1855. Doctor Antonio; a tale, Galignani, Paris.

Semeria, F. 1871. Bordighera e il suo clima, Ghilini, Oneglia.

Thomson, R. 2018. Monet and Architecture National Gallery, London.

Viacava, L. 1996. Lodovico Winter giardiniere di Bordighera, Erga, Genova.

Walker, S. W. M. 1868. 'Bordighera as a Winter Resort'. The Lancet 92, 797.

Watkins, C. 2014. Trees, Woods and Forests, Reaktion, London.

Watkins, C. 2018. Trees in Art, Reaktion, London.

Williamson, T., Barnes, G. and Pillatt, T. 2017. Trees in England: Management and disease since 1600, University of Hertfordshire Press, London.

Zanini, A. 2012. Un secolo di turismo in Liguria. Dinamiche, percorsi, attori, FrancoAngeli, Milan. 
Figures

Map

FIGURE 1 


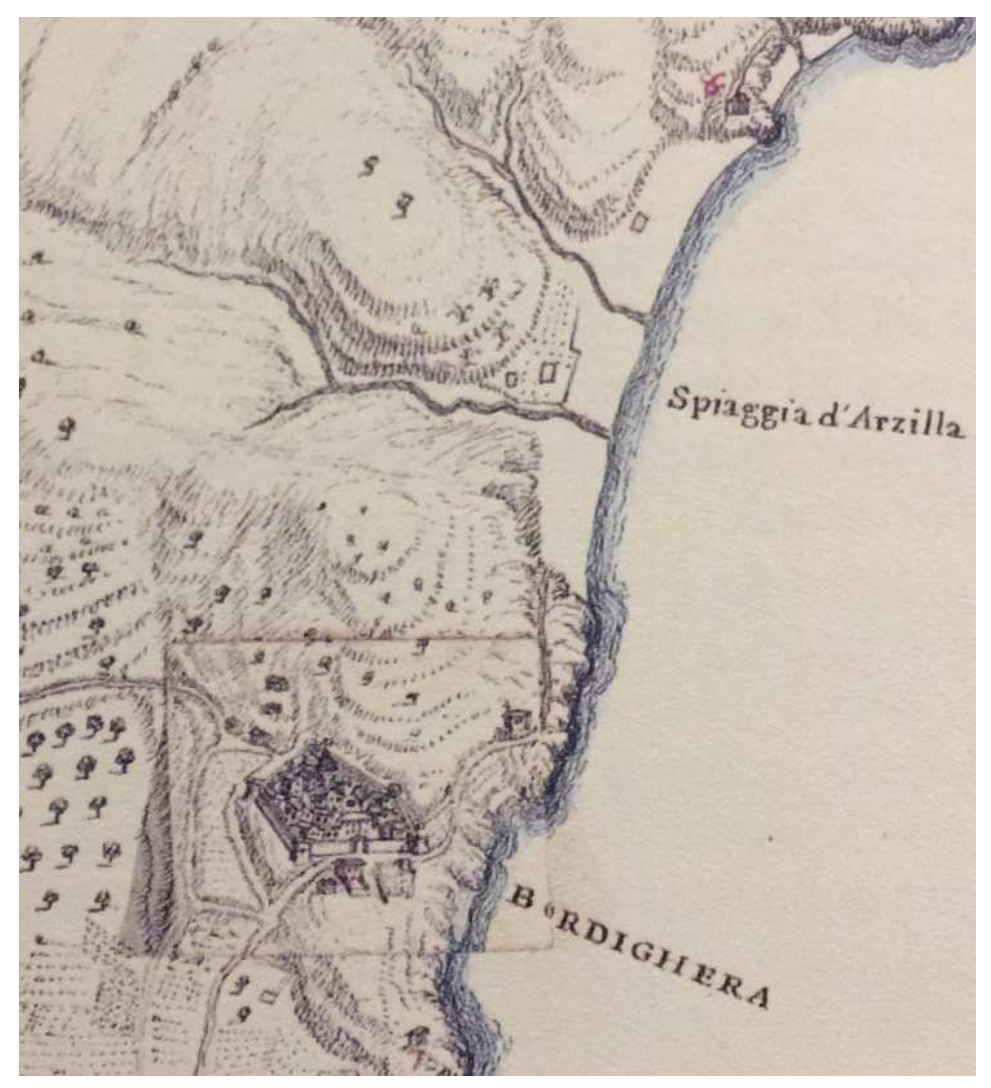

\section{FIGURE 2}

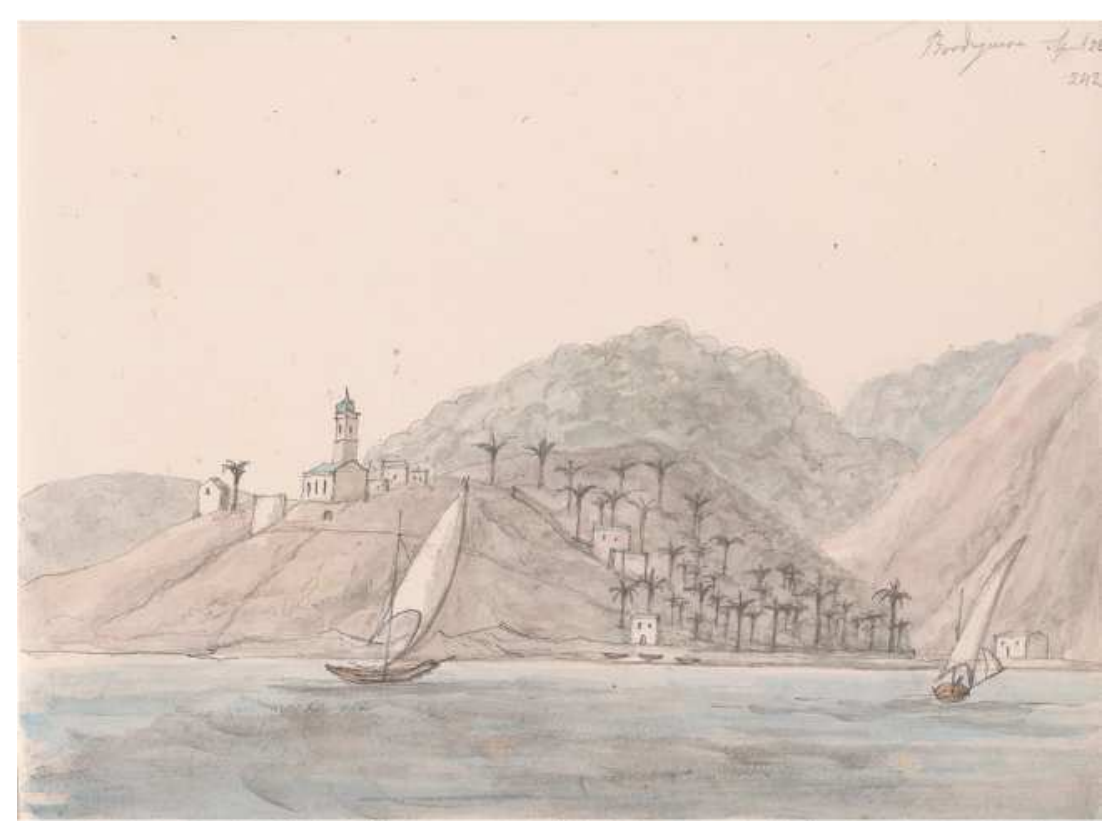

FIGURE 3 


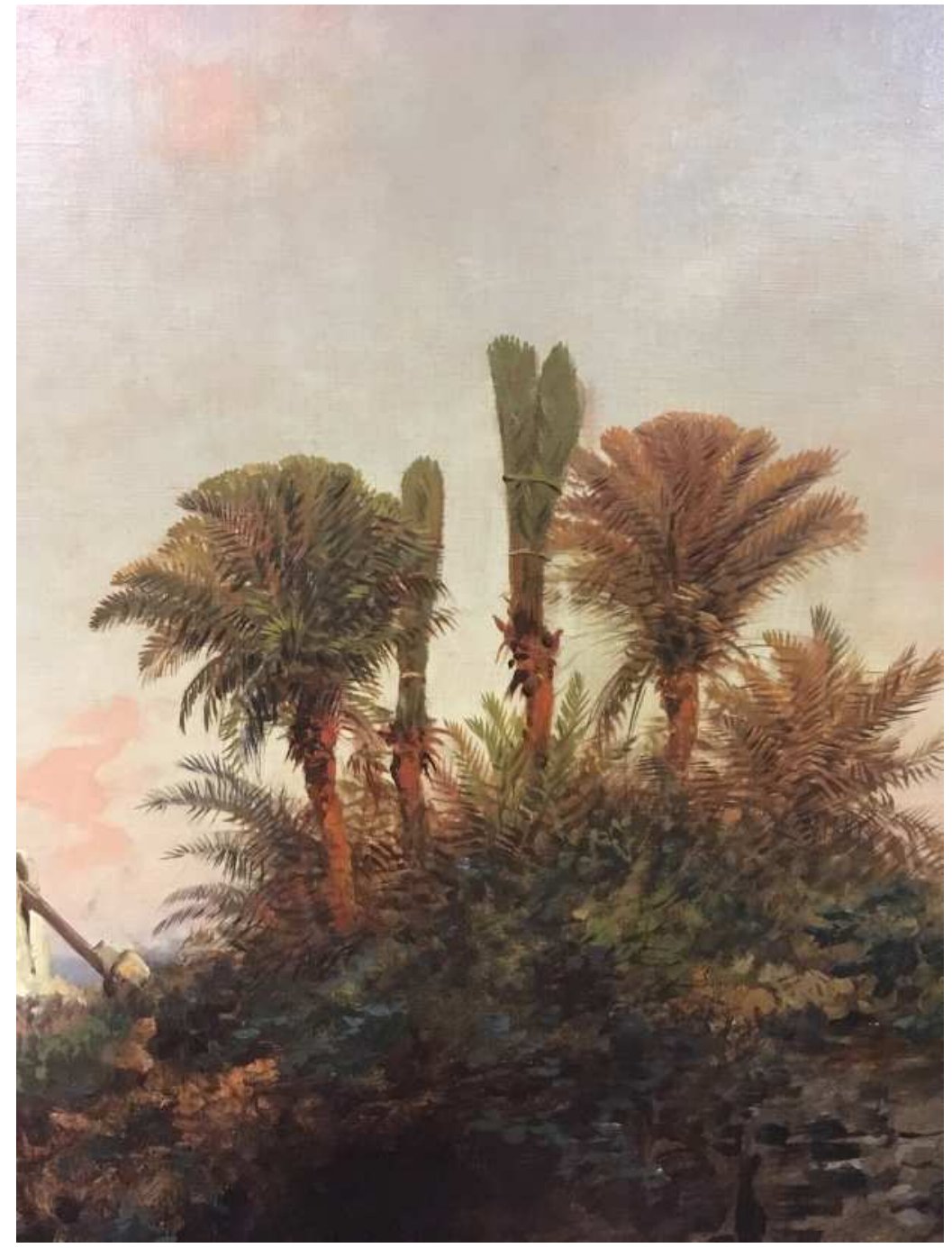

FIGURE 4 


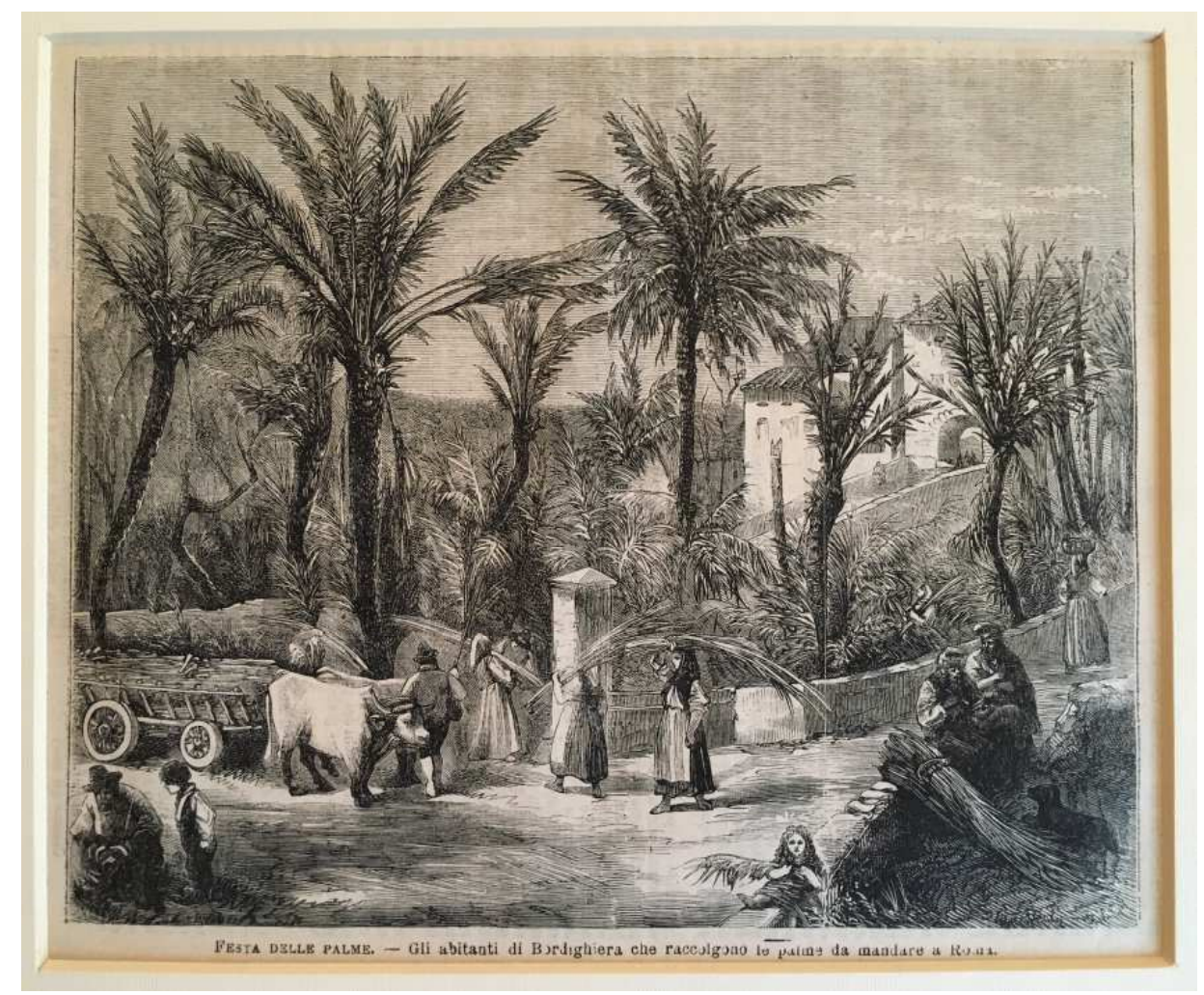

\section{FIGURE 5}

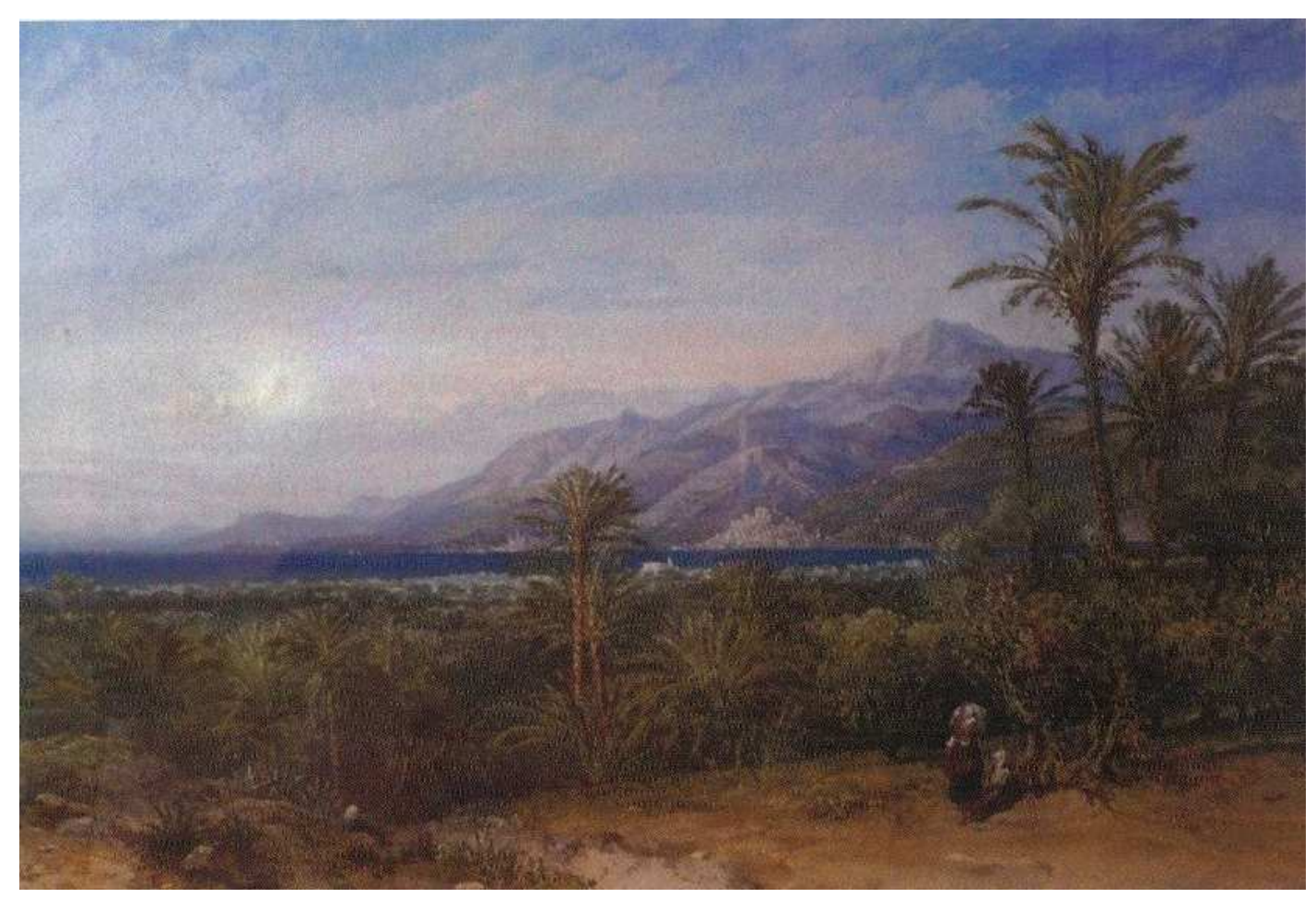

FIGURE 6 


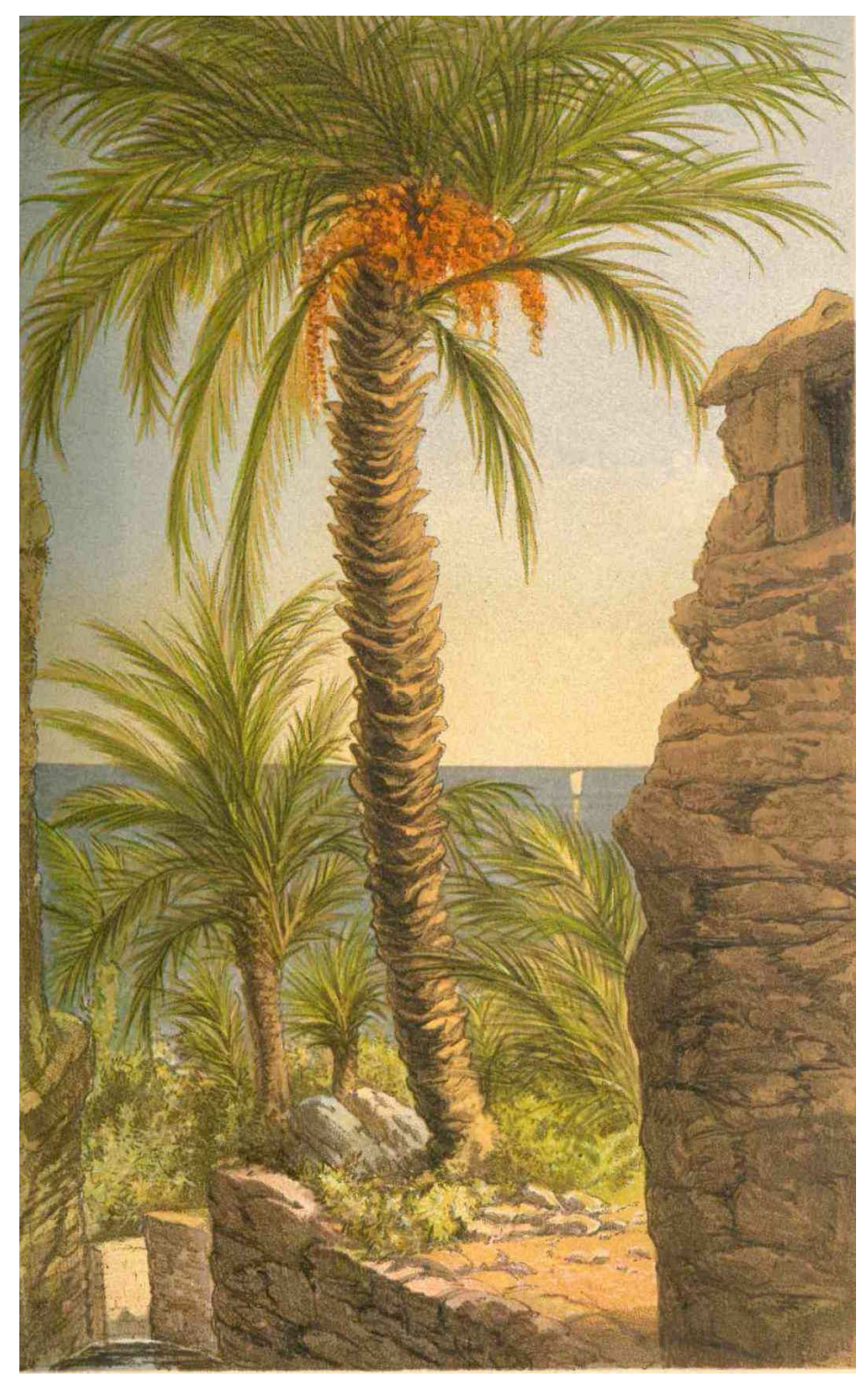

FIGURE 7 


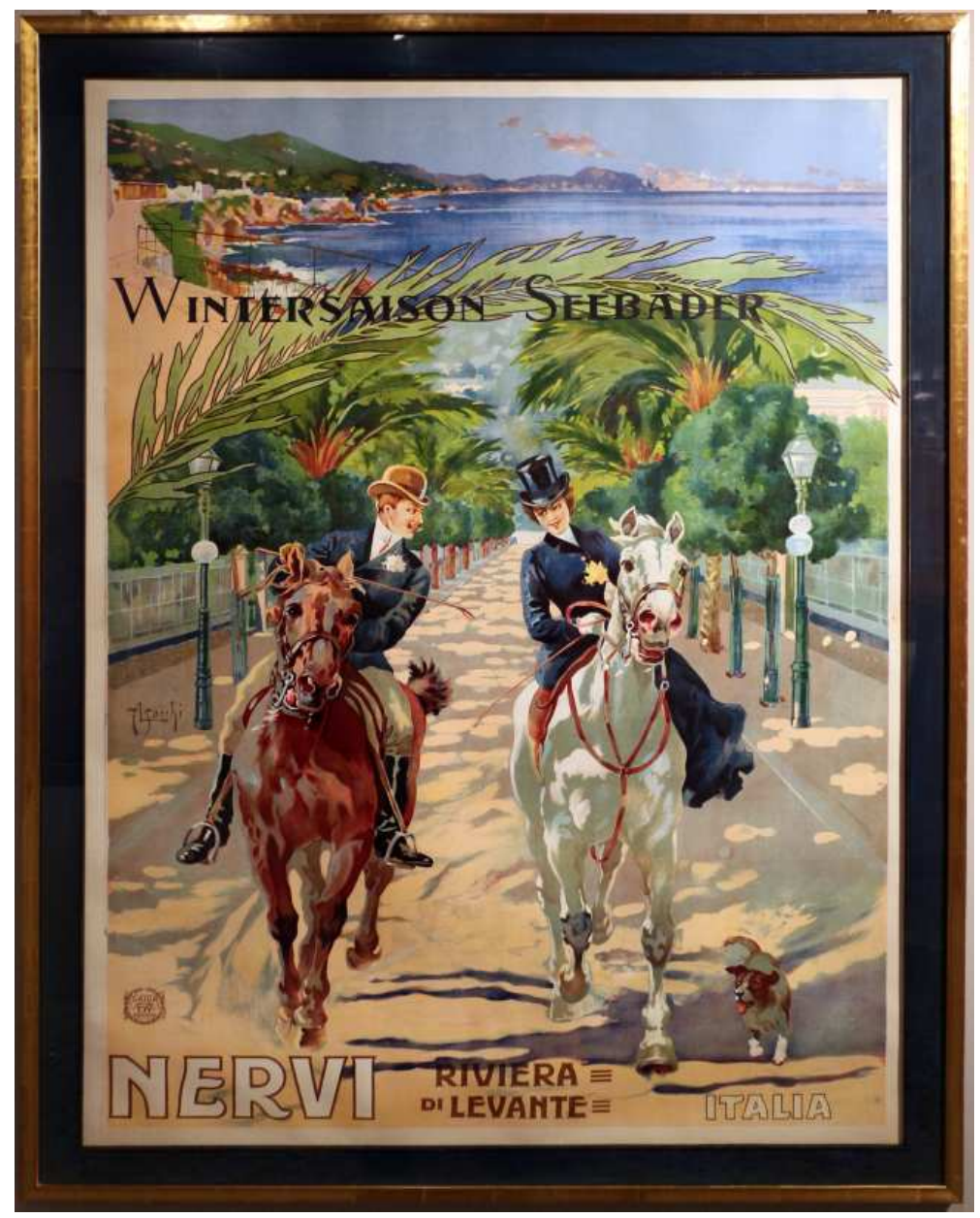

FIGURE 8 


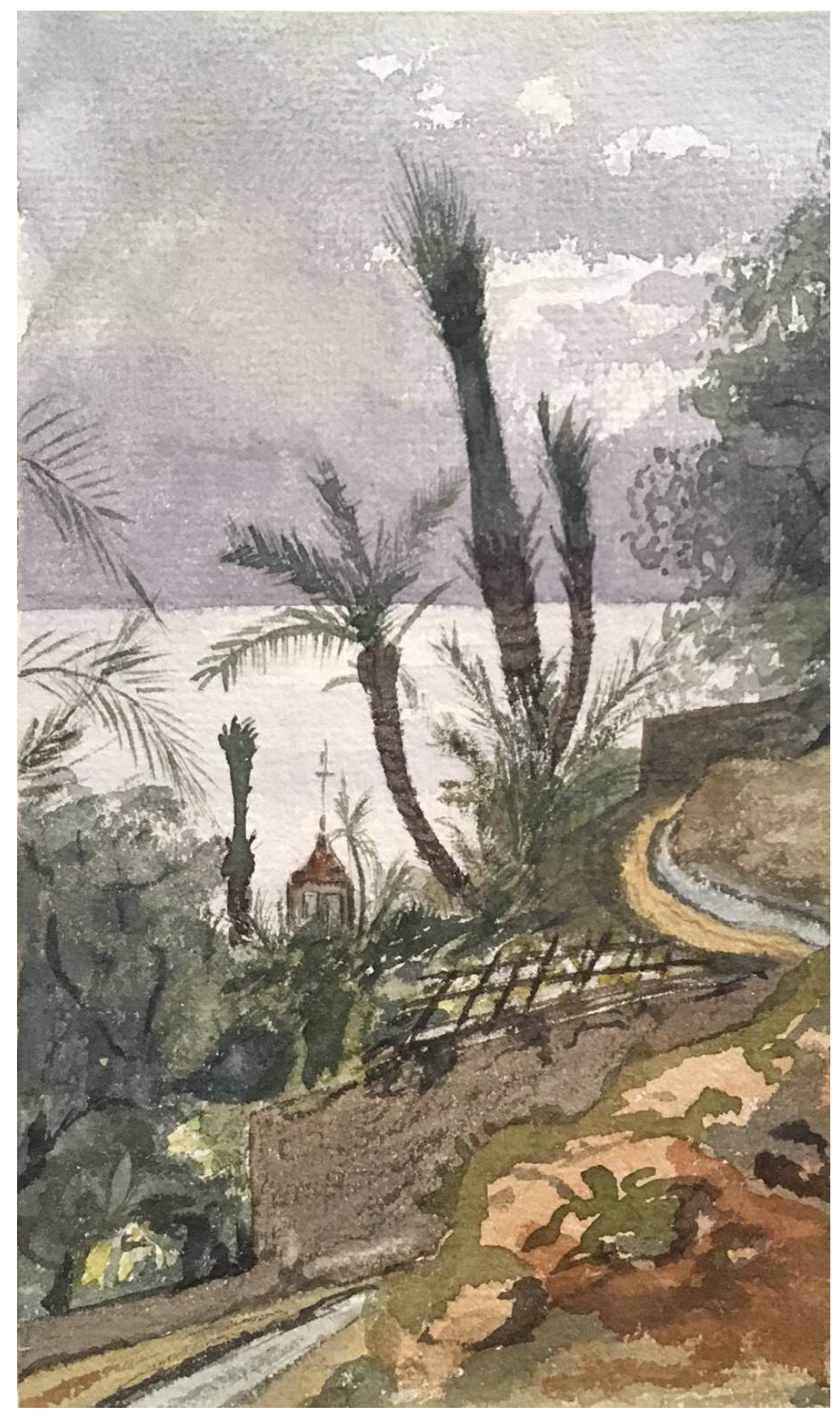

FIGURE 9 


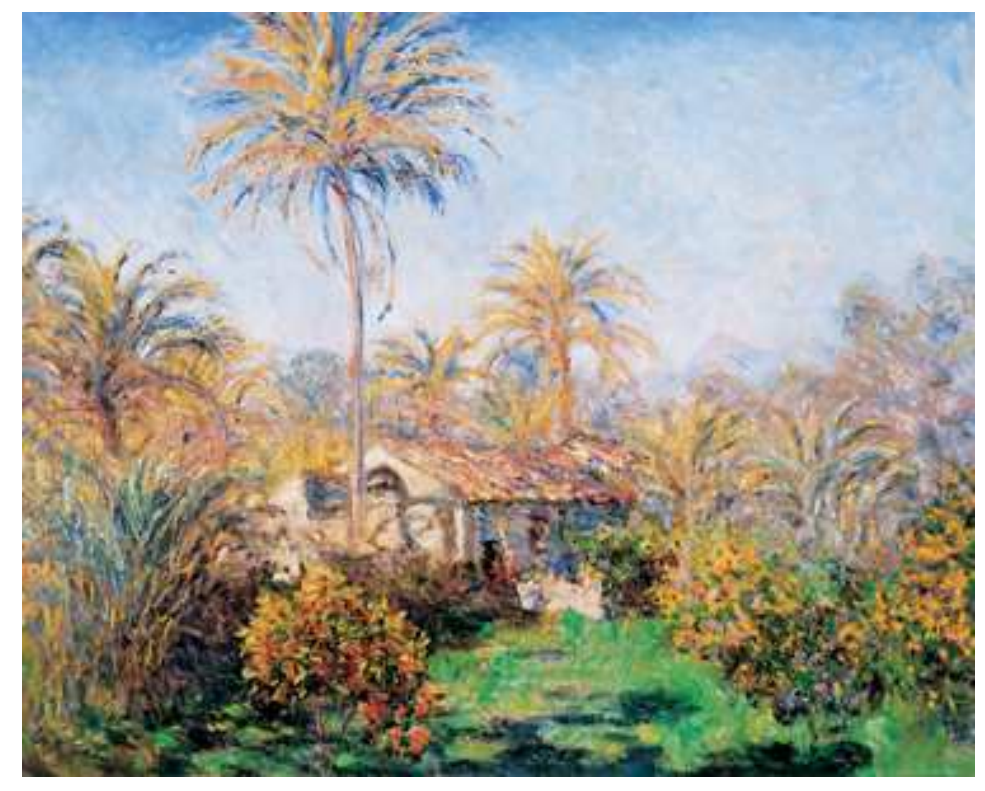

FIGURE 10

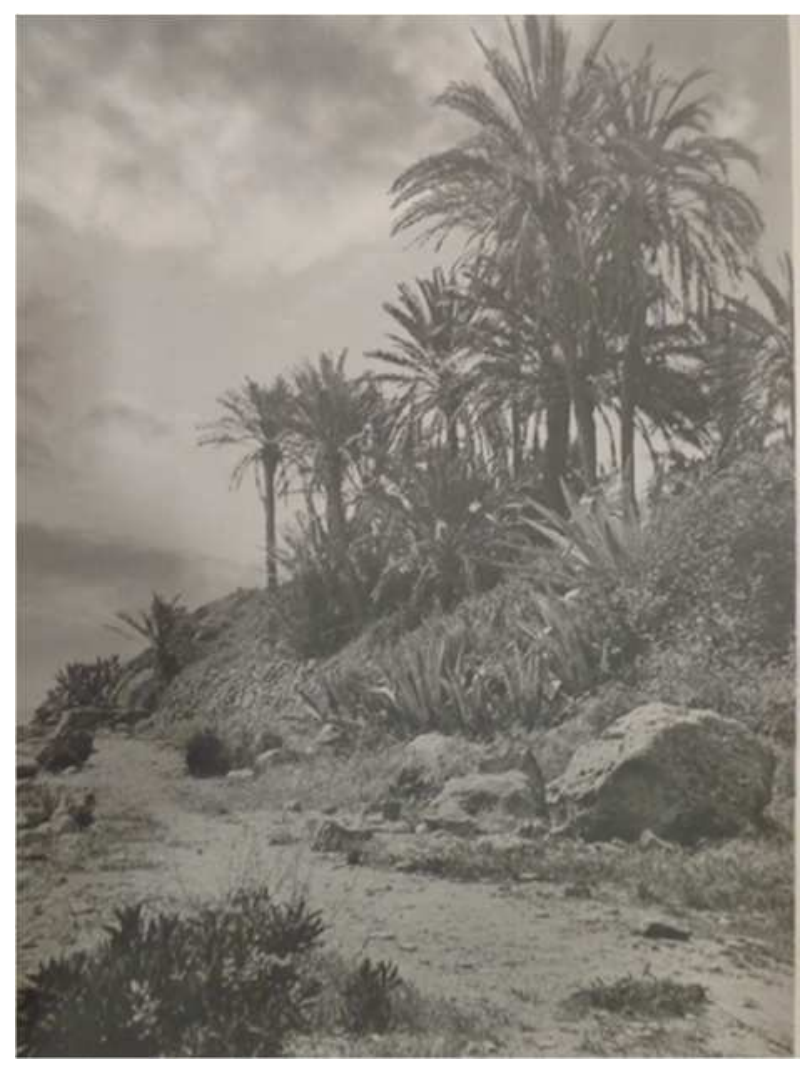

FIGURE 11 


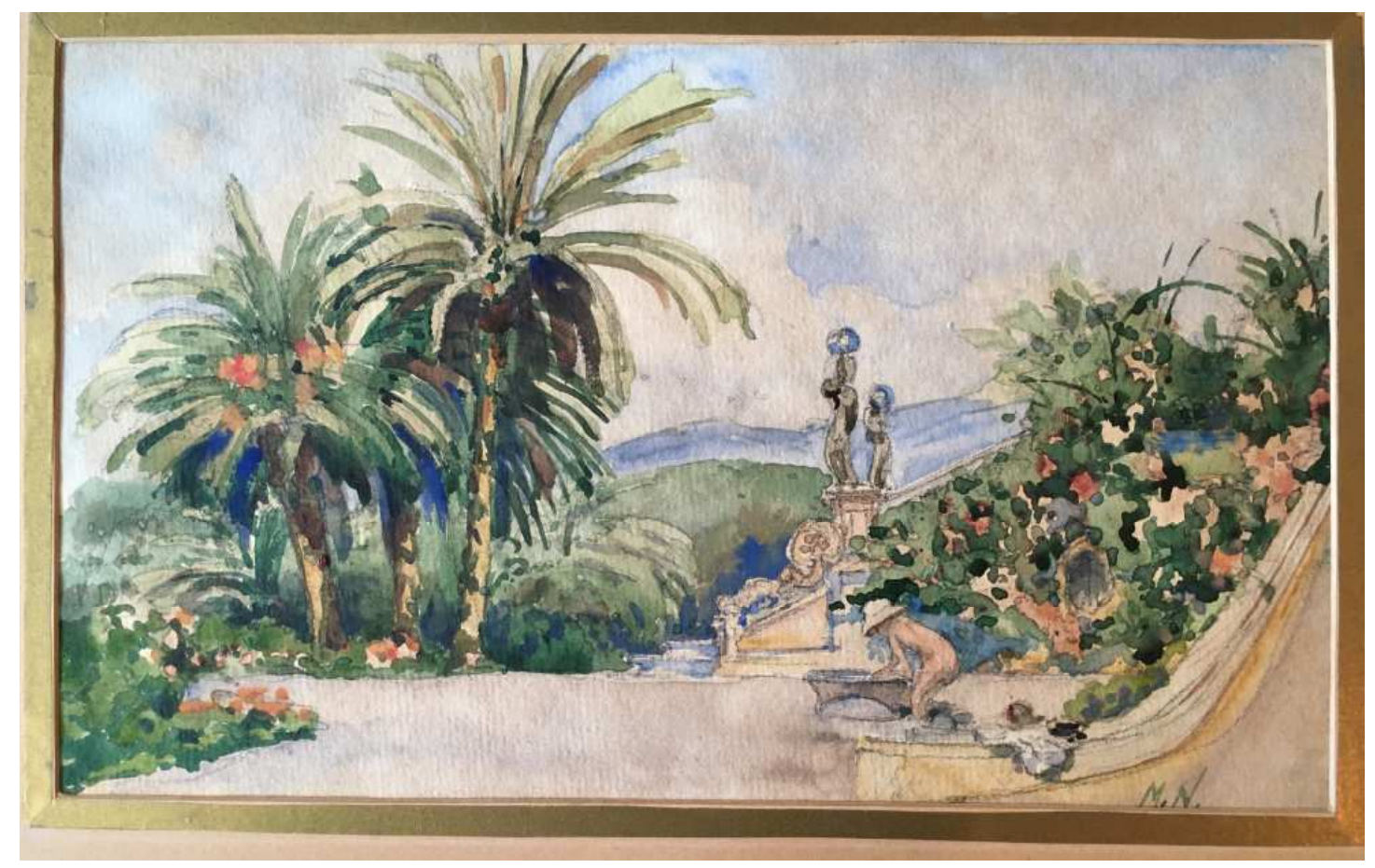

FIGURE 12

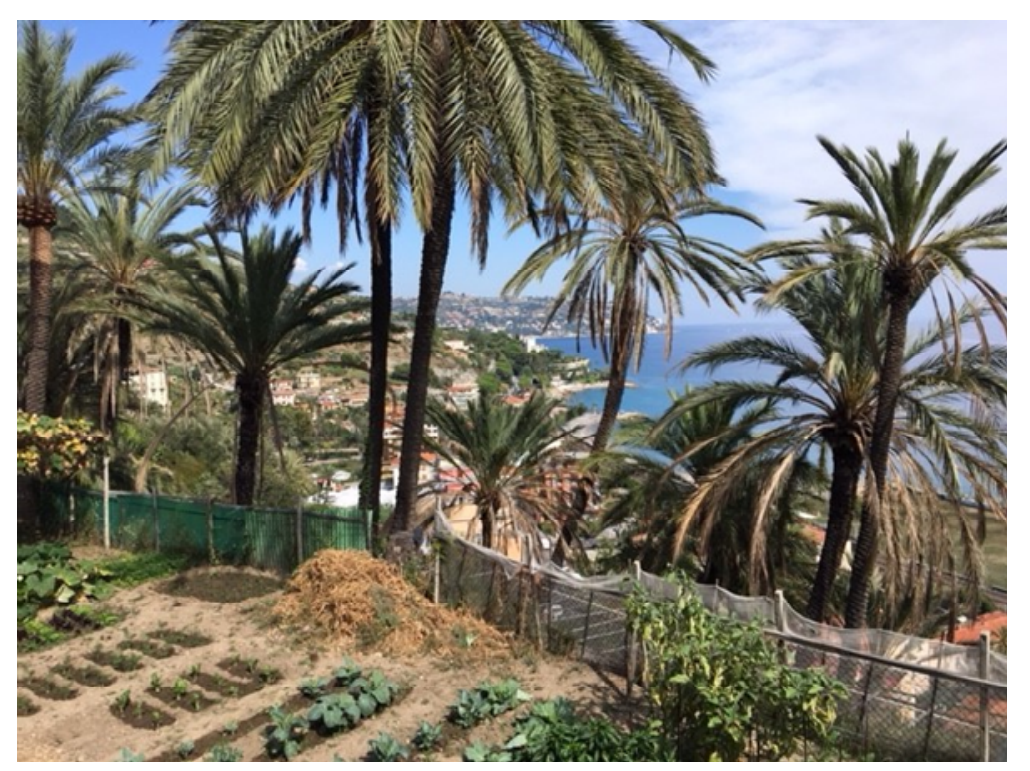

FIGURE 13 


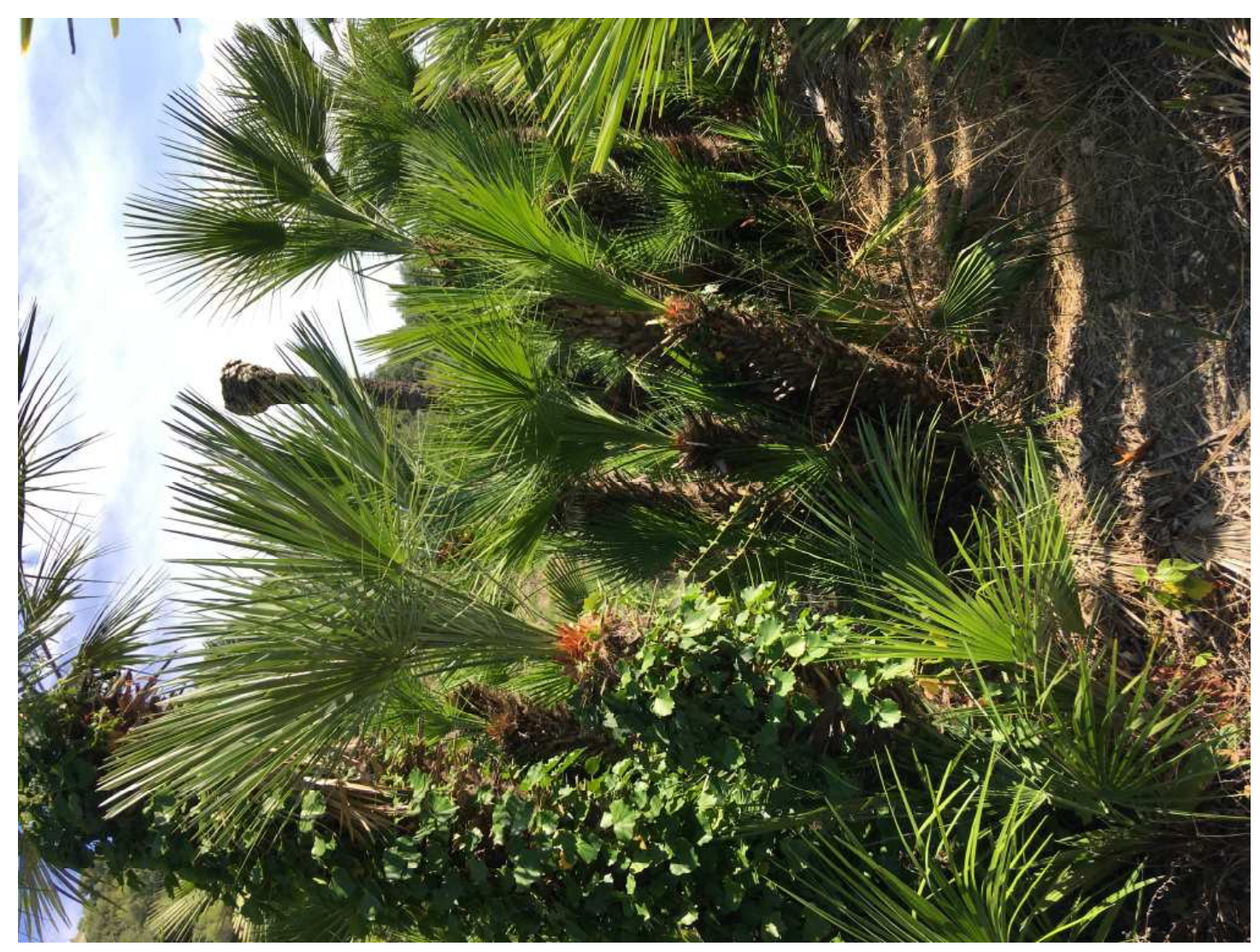

FIGURE 14

\section{Figure captions}

FIGURE 1 Map showing principal places mentioned in the text

FIGURE 2 Matteo Vinzoni, (1743) Pianta della Due Riviere della Serenissima Repubblica di Genova divise nei Commissariati di Sanitá (Quaini, 1983)

FIGURE 3 Bordighera April 26, Grand tour watercolor albums, 1793-1842, album X watercolor and graphite, Yale Center for British Art, Paul Mellon Fund

FIGURE 4 Ascan Lutteroth, Scheffel's Palms, 1883, detail showing tied palms (Bessone collection, Bordighera) 
FIGURE 5 Festa delle Palme - Gli abitanti di Bordighera che raccolgono le palme da mandare a Roma, 1873 (Bessone collection, Bordighera)

FIGURE 6 William Wyld 1863 (Bessone collection, Bordighera)

FIGURE 7 Henry Alford, Behind Bordighera (from Alford 1870, p. 74)

FIGURE 8 Agostino Luigi Sacchi c. 1905, Nervi, Riviera di Levante, Italia

FIGURE 9 The water canal of the Val di Sasso with tied palms (Bessone collection, Bordighera)

FIGURE 10 Claude Monet, Small Country Farm at Bordighera (Un coin de ferme à Bordighera), 1884 oil on canvas, 73.98 x $92.4 \mathrm{~cm}$ Museum purchase, Joslyn Endowment Fund, 1943.39

FIGURE 11 Geoffrey Ronald Ballance, Bordighera, c. 1920, DocSai Comune di Genova, collezione fotografica

FIGURE 12 Max Nadenbousch, c. 1920, Scalone Hotel Angst da Est. Anita nella tinozza (Bessone collection, Bordighera)

FIGURE 13 Palms (Phoenix dactylifera) and gardens in Val di Sasso (September 2018)

FIGURE 14 Largely abandoned plantations of Chamaerops humilis in Val di Sasso (September 2018) 